\title{
ランダムウォーク粒子追跡法による 不均質帯水層内の溶質マクロ分散評価 \\ USE OF RANDOM WALK PARTICLE TRACKING FOR MACRODISPERSION ASSESSMENT OF SOLUTE IN HETEROGENEOUS AQUIFERS
}

\author{
井上一哉 ${ }^{1} \cdot$ 藤原隆之 $^{2} \cdot$ 田中勉 $^{3}$ \\ Kazuya INOUE, Takayuki FUJIWARA and Tsutomu TANAKA \\ 1 正会員 博士(農学) 神戸大学准教授大学院農学研究科（干657-8501 神戸市灘区六甲台町1-1） \\ 2 学生会員 神戸大学農学部（干657-8501 神戸市灘区六甲台町1-1） \\ 3 正会員 農博 神戸大学教授 大学院農学研究科（ㅎ657-8501 神戸市灘区六甲台町1-1）
}

\begin{abstract}
Conservative and sorptive transport simulations were conducted in heterogeneous aquifers to assess characteristics of macrodispersion. Heterogeneities in subsurface materials were represented as randomly correlated hydraulic conductivity and sorption partition coefficient fields. Transport computations were based upon a random walk particle tracking model linked with temporal and spatial moments. The simulations demonstrated that control plane and its middle element provide almost identical macrodispersivity estimates in terms of transverse mixing, but differ markedly from estimates of longitudinal mixing. The results also indicated that the increase of the physical or chemical heterogeneity provides the increase of the longitudinal and transverse macrodispersivities and affects late traveltimes of particles reaching a control plane, leading to the increase of the second-order temporal moment and relevant macrodispersion.
\end{abstract}

Key Words: random walk particle tracking, macrodispersion, spatio-temporal moment, physical and chemical heterogeneity, travel time

\section{1. 緒論}

地下水の流れや帯水層内を移動する水溶性物質の輸送 挙動は地盤の不均質性, 寸なわち透水係数の空間分布状 態に大きく影響を受ける1). この点はフィールド実験に より広く認識されている 2,3$)$ ものの, 対象場の不均質性 と溶質輸送，特にマクロ分散に関する量的議論は現在も 継続している．空間内で不規則にばらついて分布する透 水係数や有効間隙率を精緻に捉えることは極めて困難で あり，特に，対象場を数值モデル化する際には不確実性 の問題が生じる.また，フィールド調査におけるマクロ 分散の推定結果は観測点の位置や数, サンプリング方法 に依存する点と, 高不均質の場ほど不確実性は増加する 点がマクロ分散推定を複雑にしている4).

そのため, 対象場の溶質輸送現象を確率統計的に扱う ことにより, 理論的 ${ }^{1,5)}$, あるいは数值解析的観点6)から スケール依存性を伴うマクロ分散の定量評価が進められ ている7)。 フィールド実験における濃度データの解釈を 鑑みると, 観測点での破過曲線に基づく時間モーメント 法 ${ }^{8)}$ や同一時刻における複数点での濃度計測に基づく空 間モーメント法 ${ }^{4)}$ はマクロ分散量を推定する1つの手段と
して活用されている. 両手法を溶質輸送の数值解析に組 み込んだ研究はいくつかなされている9,10)ものの, 縦方 向への分散に力点を置く傾向にあり，横方向へのマクロ 分散を評価する事例は少ない. また, 反応性トレーサの ような吸脱着を伴う物質に対する検討実績も少なく6,9), 透水係数分布のような物理的不均質性とともに化学的不 均質性に対する結果も蓄積されていくことが望まれる. そこで本研究では, 物理的・化学的不均質度の異なる模 擬透水場を対象に，時間・空間モーメント法とランダム ウォーク粒子追跡法を連携し, 不均質度とマクロ分散長 の関係を求めた。本研究では，間隙スケールでの多孔質 特性に起因した流速分布による分散をミクロ分散, 自然 地盤のような巨視的スケールでの透水係数の空間変動に 起因した流速分布による分散をマクロ分散と定義する5).

\section{2. ランダムウォーク粒子追跡法とマクロ分散推定}

\section{(1) 浸透流解析}

本研究では，図-1に示す領域を対象として，不均質流 れ場における浸透流方程式を扱った ${ }^{11)}$. 


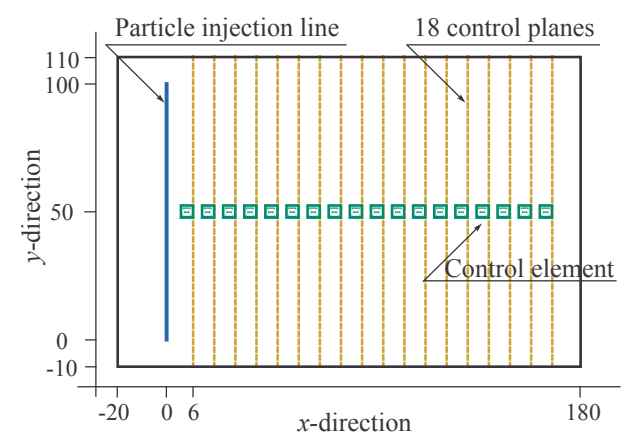

図-1 解析対象領域

$$
\sum_{i=1}^{2} \frac{\partial}{\partial x_{i}}\left(K_{i} \frac{\partial h}{\partial x_{i}}\right)=0
$$

ここに，hはピエゾ水頭， $K_{i}$ は各軸方向の透水係数であ り等方性を仮定する。 また， $x_{i}$ は座標であり，添字の 1 と 2はそれぞれ， $x$ とy軸を表す，主たる流れ方向を $x$ 軸方向の みに拘束するため, $x=-20 \mathrm{~m}$ と $x=180 \mathrm{~m}$ の面を 0.001 の動水勾配となる水頭境界, $y=-10 \mathrm{~m}$ と $y=110 \mathrm{~m}$ の面 を不透水境界に設定し, 有限要素解析により水頭分布を 導出した. 次に, 浸透場の間隙率 $n_{p}$ を 0.2 とし, Darcy 則により実流速ベクトル成分 $v_{i}$ の空間分布を求めた.

$$
v_{i}=-\sum_{i=1}^{2} \frac{K_{i}}{n_{p}} \frac{\partial h}{\partial x_{i}}
$$

\section{(2) 透水係数分布モデル}

空間的なばらつきを有する模擬透水場を確率統計的に 発生させるため, 対象場の透水係数は対数正規分布に従 い, 特定のバリオグラムに従って分布すると仮定した ${ }^{12)}$. 次に, 所定の領域内に一様乱数にて, $10^{3}$ 個のソース点 を生成し，各点に既定の対数正規分布に従う透水係数を 乱数により発生させた ${ }^{13)}$. 対象領域の分割要素の透水 係数をソース点の透水係数からBlock Kriging 予測 ${ }^{12)}$ し, $1 つ$ 不均質度に対して，10 2 個の模擬透水場 $\left(10^{2}\right.$ リ アライゼーション）を生成した。比較的透水性の良い 場 ${ }^{2,10)}$ を想定して, 透水係数の幾何平均を $116.7 \mathrm{~m} / \mathrm{day}$ とし，不均質度を広く考慮するため， $0.09 ， 0.25,1.0$, 2.25 の種類の幾何分散 $\sigma_{\ln K}^{2}$ を対象とした. また, 透水 係数の空間相関は等方とし，相関長 $\lambda を 10 \mathrm{~m}$, シルに幾 何分散を用いて, 指数型バリオグラム $\gamma$ を採用した.

$$
\gamma(h)=\sigma_{\ln K}^{2}(1-\exp (h / \lambda))
$$

ここに，hは観測点間距離である。一連のパラメータ選 定にあたっては，具体的なサイトデータではなく，現実 の值と大きく乘離しない值に設定した。各不均質度に対 する透水係数分布の一例を図-2に示す.

\section{(3) ランダムウォーク粒子追跡法}

マスバランスを維持しつつ, 溶質の空間分布状態に基 づいてマクロ分散を精度良く推定するため, 本研究で
は，ランダムウォーク粒子追跡法2,6)を適用した。

$$
\begin{gathered}
X_{p, i}(t+\Delta t)=\left(v_{i}\left(\vec{X}_{p}(t)\right)+\sum_{j=1}^{2} \frac{\partial D_{i j}}{\partial x_{j}}\left(\vec{X}_{p}(t)\right)\right) \Delta t / R\left(\vec{X}_{p}(t)\right) \\
+\sum_{j=1}^{2} B_{i j}\left(\vec{X}_{p}(t)\right) \Xi_{j} \sqrt{\Delta t}+X_{p, i}(t), \quad i=1,2
\end{gathered}
$$

ここに, $X_{p, i}(t)$ は時間 $t$ の粒子位置の $i$ 成分, $\vec{X}_{p}(t)$ は粒子 位置ベクトル, $\Delta t$ は時間増分, $\Xi_{j}$ は平均 0 , 分散 10 正規 乱数, $R$ は遅延係数, $D_{i j}$ は分散係数テンソルである ${ }^{11)}$.

$$
D_{i j}=\left(\alpha_{T}|\boldsymbol{v}|+D_{d}\right) I_{i j}+\left(\alpha_{L}-\alpha_{T}\right) \frac{v_{i} v_{j}}{|\boldsymbol{v}|}, i, j=1,2
$$

ここに， $\alpha_{L}$ はミクロ縦分散長， $\alpha_{T}$ はミクロ横分散長, $|v|$ は流速のノルム, $I_{i j}$ は単位マトリクス, $D_{d}$ は有効拡散 係数でありゼロとする. $B_{i j}$ は変位マトリクスである.

$$
B_{i j}=\left(\begin{array}{ll}
\frac{v_{1}}{|\boldsymbol{v}|} \sqrt{\frac{2\left(\alpha_{L}|\boldsymbol{v}|+D_{d}\right)}{R}} & -\frac{v_{2}}{\sqrt{v_{1}^{2}+v_{2}^{2}}} \sqrt{\frac{2\left(\alpha_{T}|\boldsymbol{v}|+D_{d}\right)}{R}} \\
\frac{v_{2}}{|\boldsymbol{v}|} \sqrt{\frac{2\left(\alpha_{L}|\boldsymbol{v}|+D_{d}\right)}{R}} & \frac{v_{1}}{\sqrt{v_{1}^{2}+v_{2}^{2}}} \sqrt{\frac{2\left(\alpha_{T}|\boldsymbol{v}|+D_{d}\right)}{R}}
\end{array}\right)
$$

透水係数に関わる物理的不均質性に加えて，負の相関 モデル6)を用いて，透水係数分布に応じた分配係数の空 間分布，すなわち遅延係数の不均質性を考慮した。

$$
R(\boldsymbol{x})=1+\rho_{b} K_{d g} \exp (\beta(\ln K(\boldsymbol{x})-\langle\ln K\rangle)) / n_{p}
$$

ここに，xは位置ベクトル， $K_{d g}$ は分配係数の幾何平均, $\langle\ln K\rangle$ は透水係数の幾何平均, $\beta$ は分配係数と透水係数の 相関性を表すモデル定数である。 また, 文献 6)に基づ き, 定数 $\beta$ の值は- 0.3 と $-0.1, K_{d g}$ は $0.526 \mathrm{~cm}^{3} / \mathrm{g}$ に設定 した. さらに, 分散の影響を大きくするため, 縦分散長 と横分散長をそれぞれ $0.1 \mathrm{~m}, 0.01 \mathrm{~m}$ とた。一連のパ ラメータを表-1に示す. 遅延係数の不均質度 $\sigma_{R}^{2}$ は透水係 数の不均質度と負の相関モデル定数に応じて変化するた め, 表中には取り得る範囲を記す。このとき, 遅延係数 の平均值は1から5.77である。

\section{(4) 時間モーメント法}

図-1に示すように, 本解析では18の評価面(Control plane: CP)を設けて, 各面を通過する粒子群の時間的な 質量変化を基に，粒子質量の破過曲線を求めた．全リア ライゼーションをアンサンブル平均した破過曲線のn次 時間モーメント $M_{n, T}$ は次式から求めた ${ }^{9)}$.

$$
M_{n, T}=\frac{1}{N_{r}} \sum_{r=1}^{N_{r}}\left(\sum_{k=1}^{N P_{s}} m_{p}^{k}\left(t_{p}^{k}\left(\xi_{1}\right)\right)^{n} / \sum_{k=1}^{N P_{s}} m_{p}^{k}\right)^{(r)}
$$

ここに, $m_{p}^{k}$ は $k$ 番目の粒子質量, $\xi_{1}$ は評価面の $x$ 座標, $N P_{s}$ は評価面を通過する粒子数, $t_{p}^{k}$ は $k$ 番目の粒子の評価面通 過時間, $N_{r}$ はリアライゼーション数, カッコ付きの上添 字はリアライゼーション番号である. また, n次中心時 間モーメント $\Lambda_{n, T}$ は二項定理を用いて次式から求めた.

$$
\Lambda_{n, T}=\sum_{r=0}^{n}\left(\begin{array}{l}
n \\
r
\end{array}\right) M_{n-r, T}\left(\xi_{1}\right)\left(-M_{1, T}\left(\xi_{1}\right)\right)^{r}
$$



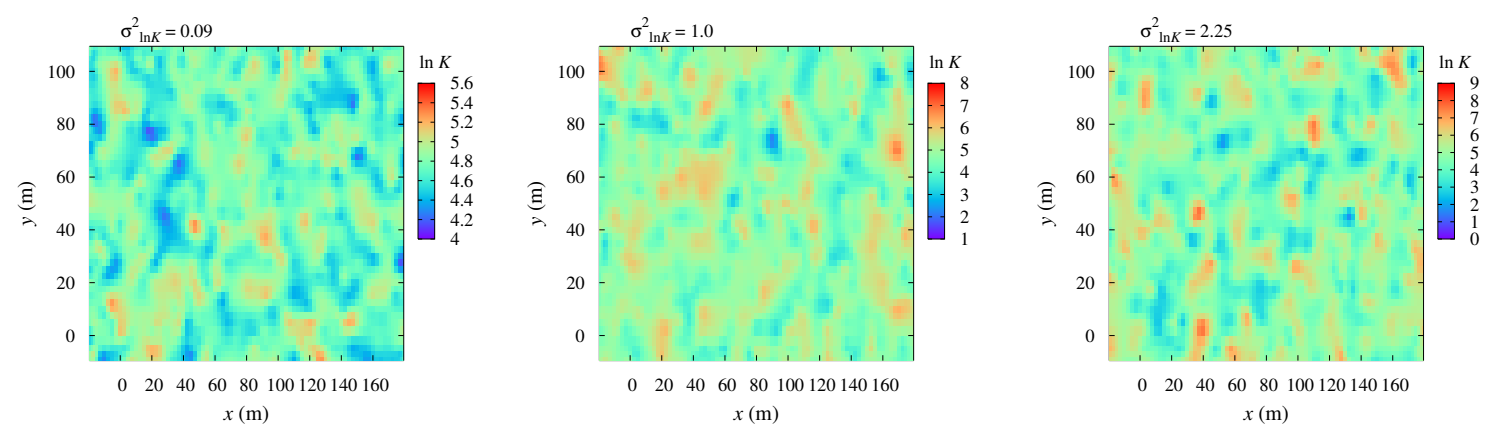

図-2 物理的不均質度に対する透水係数分布の一例

表-1 ランダムウォーク粒子追跡解析に用いるパラメーター覧

\begin{tabular}{lr|lr}
\hline 平均透水係数 $(\mathrm{m} /$ day $)$ & 116.7 & 相関長 $\lambda(\mathrm{m})$ & 10 \\
動水勾配 $J(-)$ & 0.001 & 間隙率 $n_{p}(-)$ & 0.2 \\
ミクロ縦分散長 $\alpha_{L}(\mathrm{~m})$ & 0.1 & ミクロ横分散長 $\alpha_{T}(\mathrm{~m})$ & 0.01 \\
乾燥密度 $\rho_{b}\left(\mathrm{~g} / \mathrm{m}^{3}\right)$ & $1.8 \times 10^{6}$ & 負の相関モデル定数 $\beta(-)$ & $-0.3,-0.1,0$ \\
粒子数 & $2 \times 10^{5}$ & 分配係数 $K_{d}\left(\mathrm{~m}^{3} / \mathrm{g}\right)$ & $0,5.26 \times 10^{-7}$ \\
粒子啠量 $m(\mathrm{~g})$ & $1.0 \times 10^{-3}$ & 時間ステップ $\Delta t($ day $)$ & 1.0 \\
透水係数の不均質度 $\sigma_{\ln K}^{2}\left(\mathrm{~m}^{2} / \mathrm{day}^{2}\right)$ & $0.09,0.25,1,2.25$ & 遅延係数の不均質度 $\sigma_{R}^{2}(-)$ & $0 \sim 1.26$ \\
\hline
\end{tabular}

マクロ縦分散長 $A_{11}$ とマクロ横分散長 $A_{22}$ は,

$$
\begin{aligned}
& A_{11}\left(\xi_{P}\right)=\frac{\xi_{P}}{2} \frac{\Lambda_{2, T}\left(\xi_{P}\right)}{\left(M_{1, T}\left(\xi_{P}\right)\right)^{2}} \\
& A_{22}\left(\xi_{P}\right)=\frac{1}{N_{r}} \sum_{r=1}^{N_{r}}\left(\frac{1}{2 \xi_{P}} \sum_{k=1}^{N P_{a}} m_{p}^{k}\left(\Delta b_{p}^{k}\left(\xi_{P}\right)\right)^{2} / \sum_{k=1}^{N P_{a}} m_{p}^{k}\right)^{(r)}
\end{aligned}
$$

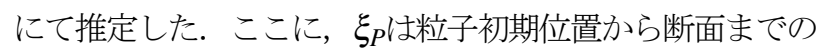
距離, $N P_{a}$ は該当断面を通過する総粒子数, $\Delta b_{p}^{k}$ は $k$ 番目 の粒子に対する初期位置から水平方向への変位量である.

\section{(5) 空間モーメント法}

空間モーメント法を用いたマクロ分散を推定するた め, 次式により空間モーメント量を算定した6).

$$
\begin{aligned}
& X_{G, i}=\frac{1}{m(t)} \sum_{k=1}^{N P_{t}} \frac{m_{p}^{k} X_{p, i}^{k}(t)}{R\left(X_{p}^{k}(t)\right)}, \quad m(t)=\sum_{k=1}^{N P_{t}} \frac{m_{p}^{k}}{R\left(X_{p}^{k}(t)\right)} \\
& S_{i j}(t)=\frac{1}{m(t)} \sum_{k=1}^{N P_{t}} \frac{m_{p}^{k} X_{p, i}^{k}(t) X_{p, j}^{k}(t)}{R\left(X_{p}^{k}(t)\right)}-X_{G, i}(t) X_{G, j}(t)
\end{aligned}
$$

ここに, $X_{G, i}$ は時間 $t$ こおける粒子空間分布に対する重心位 置を表す空間1次モーメント， $m(t)$ は時間 $t$ において空間内 に存在する粒子の総質量, $S_{i j}$ は粒子空間分布に対する空 間 2 次モーメント, $N P_{t}$ は時間 $t$ の空間内の粒子総数である.

すべてのリアライゼーションに対する空間 2 次モーメ ントのアンサンブル平均 $\Gamma_{i j}$ は次式にて導出した。

$$
\begin{aligned}
\Gamma_{i j}(t) & =\left\langle S_{i j}(t)\right\rangle \\
& +\left\langle\left(X_{G, i}(t)-\left\langle X_{G, i}(t)\right\rangle\right)\left(X_{G, j}(t)-\left\langle X_{G, j}(t)\right\rangle\right)\right\rangle
\end{aligned}
$$

ここに，〈·ははアンサンブル平均を意味する. 最後に, 縦
方向と横方向のマクロ分散長は次式により推定した.

$$
A_{i i}\left(\left\langle\xi_{G}(t)\right\rangle\right)=\frac{\Gamma_{i i}\left(\left\langle\xi_{G}(t)\right\rangle\right)}{2\left\langle\xi_{G}(t)\right\rangle}, \quad i=1,2
$$

ここに， $\xi_{G}(t)$ は時間 $t$ における粒子群の重心位置の変位 距離である。一連の数值解析には，井上ら ${ }^{10,14)}$ が開発 したランダムウォーク粒子追跡コードを使用した.

時間モーメント法は，サイトにて複数の観測井を列配 置し, 観測井群を通過する溶質濃度の時系列計測を基に マクロ分散を推定する状況に相当するのに対して，空間 モーメント法は, 対象空間に広く配置された観測井群で の一斉観測結果を基にマクロ分散を推定する状況に相当 する. そのため, 時間モーメント法は定点での破過状 態, 空間モーメント法は溶質の空間分布状態がマクロ分 散結果に影響を及ぼす。

\section{3. 結果と考察}

\section{(1) 物理的不均質性の効果}

図-1に示すように, $x=0$ の軸上に $100 \mathrm{~m}$ 的たって, $2 \times 10^{5}$ 粒子を一様に初期配置してランダムウォーク粒子 追跡解析を実施した。時間モーメント法を用いて, 設定 した評価面にてリアライゼーションごとに推定されたマ クロ分散長の值，ならびに，アンサンブル平均の結果を 検討するため, 物理的不均質度 $\sigma_{\ln K}^{2}$ が 1 , 化学的不均質性 を考慮しない $\left(\sigma_{R}^{2}=0\right)$ 透水場にて得られた縦方向と横 方向のマクロ分散長の結果を図-3に示す. 図中には, 寸 ベてのリアライゼーションのアンサンブル平均に加えて, ランダムに抽出した10個のリアライゼーションの結果を 


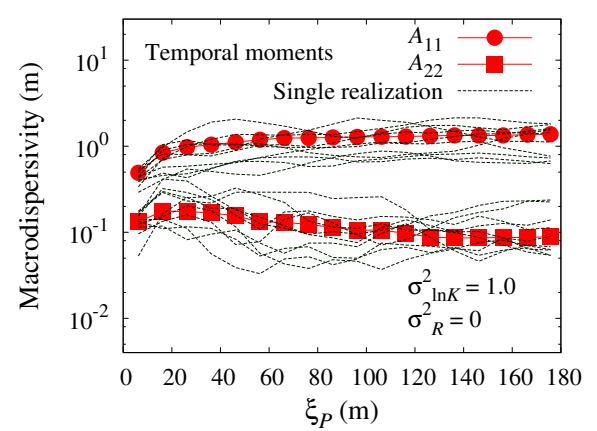

図-3 時間モーメント法によるマクロ分散推定結果

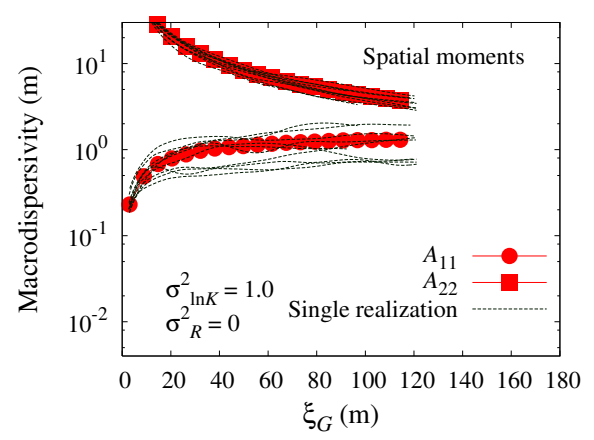

図-4 空間モーメント法によるマクロ分散推定結果

併記する. マクロ分散長と溶質の輸送距離の推移はリア ライゼーションごとに異なるものの, マクロ縦分散長 $A_{11}$ は約1.2, マク口横分散長 $A_{22}$ は約 0.09 に漸近しており, 不 均質度や輸送距離を考慮すると妥当な值 ${ }^{3}$ と考えられる.

他方，図-4には，図-3と同一の場に対して，空間モー メント法により得られた縦方向と横方向のマクロ分散長 の結果を示す，空間モーメント法を適用する際には，領 域内に生成した全粒子の存在が前提となるため, 初期配 置から領域外一移行するまでの期間が解析対象となり, 結果として, 時間モーメント法よりもマクロ分散長を推 定できる距離は短くなる．縦方向のマクロ分散長は図-3 の結果とほぼ同じ変化を示し, 約1.2に漸近する一方で, マクロ横分散長はマクロ縦分散長よりも大きい值であ る.これは初期条件にて線状配置した時点で, 重心位置 $(x=0 \mathrm{~m}, y=50 \mathrm{~m})$ から $y$ 方向一の拡がりは強制的に大き いため，式(13)のS $S_{22}$ が幾何形状に影響を受けて大きくなる ことが要因である．粒子群の移行とともに初期形状の影 響は減少するため, 横分散長は急激に低下し, 最終的に はミクロ横分散長, あるいは, マクロ縦分散長よりは小 さい対象場固有のマクロ横分散長に漸近すると推量され る. そのため, 空間モーメント法の適用に際しては, 移 行距離を長く, あるいは, 初期分布範囲を小さく寸るこ とで, 対象場固有の横分散長を推定できると考えられる.

物理的不均質性とマクロ分散長の関係を調べるため, 化学的不均質性は無く, 物理的不均質性の異なる4種類 の場に対するアンサンブル評価結果を図-5に示す．図の 縦軸には, 推定結果をミクロ分散長で除した值を設定 し, 評価距離が長く, 粒子群の初期形状への依存性が小

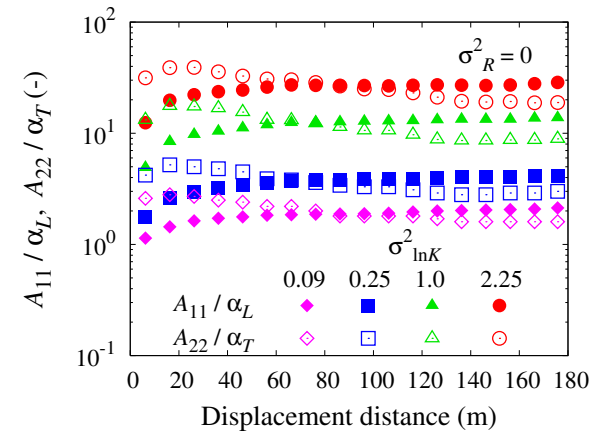

図-5 マクロ分散推定值とミクロ分散值の比の変化

さい時間モーメント法のアンサンブル評価結果を示す. 物理的不均質性の増加は粒子群の空間分布を拡大寸る方 向に作用するため, 図-5に見られるように不均質性の高 い場ほど比の值は大きくなる. 物理的不均質度が約 20 倍 変化することでマク口分散長は縦方向・横方向ともに約 10倍の変動を示している. 特に, マクロ横分散長の大き さは特徵的であり, 不均質性に対応した $y$ 方向流速成分 の影響と考えられる.この点は主たる流れ方向に並行な 成層地盤では生じにくい現象 ${ }^{10)}$ であり, 透水係数の空間 的なばらつきが溶質輸送に及ぼす影響の1つと言える.

\section{(2) 評価面と評価要素}

フィールド試験を鑑みると，物理的・経済的制約から 評価面のような同一断面内に多数の観測点を設けること は難しい，そのため, 図-1に示すように, 評価面内に評 価要素 (Control element: CE) を設け, 特定の要素のみ を通過する粒子の累積質量変化に基づいてマクロ分散長 を推定した. 図-6に物理的不均質性の異なる場における マクロ縦分散長, 図-7にマクロ横分散長の時間モーメン ト法による推定結果を示す。

マクロ縦分散に関しては, 評価面と評価要素では通過 する粒子群の累積質量が異なるため, 評価要素での推定 結果は過小評価される傾向にあるのに対して, 評価面と 評価要素に対するマクロ横分散長の結果には相違があま り見られない.これは式(11)に示すように, 横分散の推定 には粒子の初期位置からの水平変位量を用いる点に起因 する. 評価面や評価要素では, 通過する粒子固有の水平 変位量を記憶していくため, 溶質の初期重心位置から主 たる流れ方向に沿って観測井を配置すると単独の観測井 であってもマクロ横分散長の推定ができると考えられる.

信頼性の観点からフィールド試験を整理した文献による と約 $100 \mathrm{~m}$ の輸送距離に対する縦分散長と横分散長はそれ ぞれ約 $10^{0} \mathrm{~m}$, 約 $10^{-1} \mathrm{~m}$ である ${ }^{3,15)}$. この点を踏まえて, 本解析結果は一定の妥当性を有していると判断される.

\section{(3) 化学的不均質性の効果}

式(7)を用いて場の化学的不均質性を考慮すると, 遅 延係数の空間的ばらつきに対応して粒子群の輸送挙動に は変化が生じる6, 10). 本研究では, モデル定数 $\beta$ を-0.3 


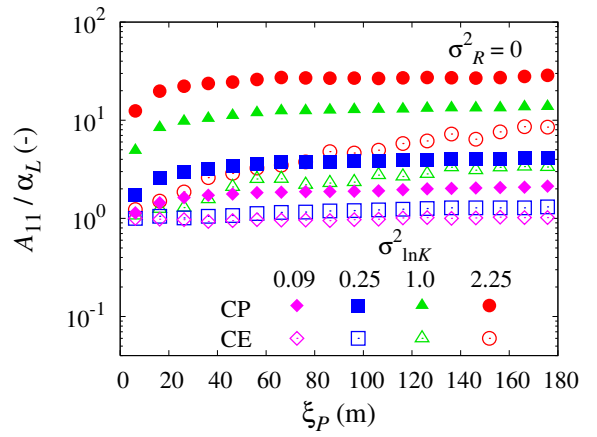

図-6 評価面と評価要素に関するマクロ縦分散の差異

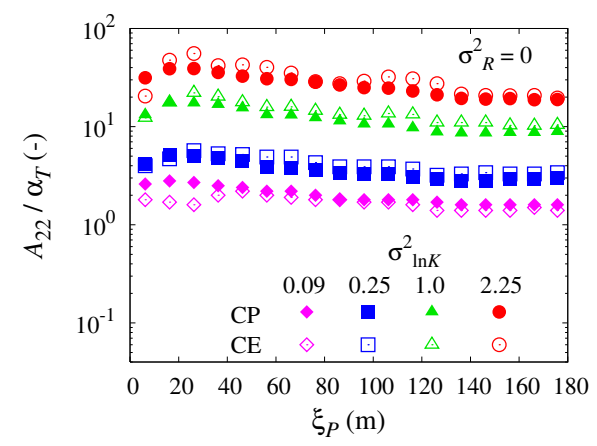

図-7 評価面と評価要素に関するマクロ横分散の差異

と-0.1に設定することで，分配係数と透水係数の相関度 合いを変えて, 化学的不均質性を考慮しない場 $(\beta=0)$ とともに解析対象とした. 物理的不均質度が最も小さい $\sigma_{\ln K}^{2}=0.09$ の透水場において, 化学的不均質性を変化さ せた場合の縦および横方向のマクロ分散長の推定結果を 図-8に示す. 図の凡例には, モデル定数 $\beta$ に応じた化学 的不均質度 $\sigma_{R}^{2}$ を記しており， $\beta$ が小さいほど化学的不均 質度は大きくなる. また, 同様に, 物理的不均質度が最 も大きい $\sigma_{\ln K}^{2}=2.25$ の透水場に対する結果を図-9に示 す. 図-3と図-4の結果と同様に，マクロ縦分散長の推移 はモーメント法の違いに依存しないが, マクロ横分散長 は初期粒子群の配置形状の影響により, モーメント法ご との差異は顕著である。したがって, 線状配置の下での 横分散推定は観測方法に大きく左右されるといえる.

化学的不均質性が高くなるほど, マクロ縦分散長は増 加し, 図-9に示寸物理的不均質性の高い場ほど化学的不 均質性の影響は顕著に現れるようになる。この点は Tompsonの研究6)においても観察されている. マクロ横 分散長に関しては，実際には数值的に微小な差異がある ものの, 化学的不均質性の影響はほとんど生じていな い. 分散の度合いは場の流速分布に左右され, 物理的不 均質性の高い場ほどy軸方向の流速成分の影響により横 分散長は増加する ${ }^{10)}$. しかしながら, 流速成分 $v_{x}$ は $v_{y} よ$ りも大きいため, 化学的不均質性の影響は縦方向に顕著 に表れ，物理的不均質性に比べると化学的不均質性の寄 与の度合いはかなり小さくなったと推察される.

ところで，不均質性の増加は任意の評価面における粒 子群の累積質量変化に変化を与えると考えられる. この

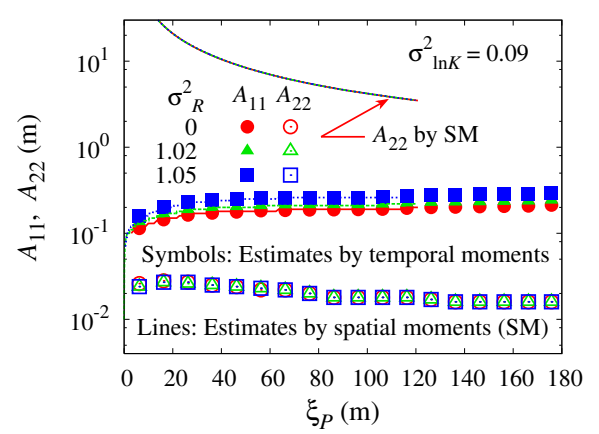

図-8 化学的不均質性に応じたマクロ分散の差異

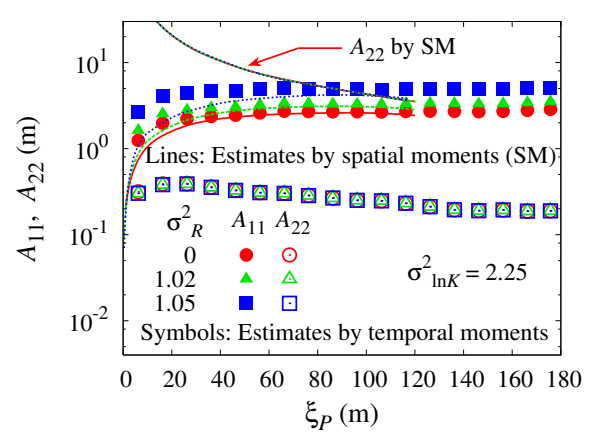

図-9 化学的不均質性に応じたマクロ分散の差異

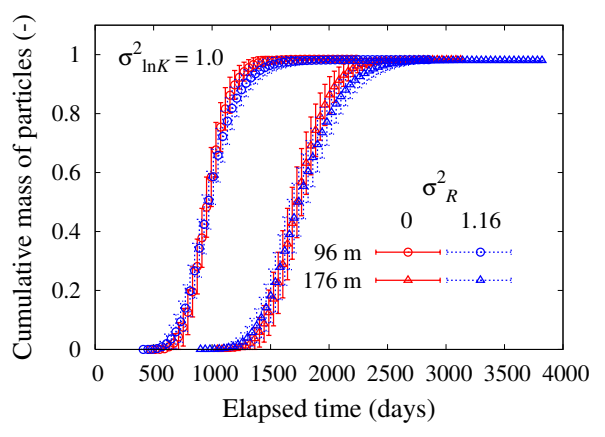

図-10 評価面における累積質量の差異

点を確認するため, $\sigma_{\ln K}^{2}=1.0$ の物理的不均質場を例 として, 化学的不均質度の異なる 2 種類の場に対する $x=96$ と $176 \mathrm{~m}$ の評価面での累積質量変化を図-10に示す. $\sigma_{R}^{2}=1.16$ のケースの横軸は, 経過時間を平均遅延係数 で除した值である. 図にはアンサンブル平均した際の標 準偏差をエラーバーとして併記している. 不均質度の高 い場ほど累積質量の変化割合が緩くなっており, 特に, 累積質量が $80 \%$ を超えてくると, その後の質量変動は小 さくなる点がマクロ分散長の推定結果に寄与している.

図-10において評価面にて累積質量の50\%に相当する 時刻は，不均質度に関わらず概初一致しており，前述の ように, 累積質量の大きい部分の差異が小さい部分より も顕著である. そこで, 物理的不均質性の異なる場ごと に, 化学的不均質性の度合いに応じた粒子群のトラベル 時間とトラベル距離を求め, 得られた関係を図-11に示 す. 図中の縦軸と横軸はそれぞれ無次元化したトラベル 時間とトラベル距離であり, 次式により求めた。 

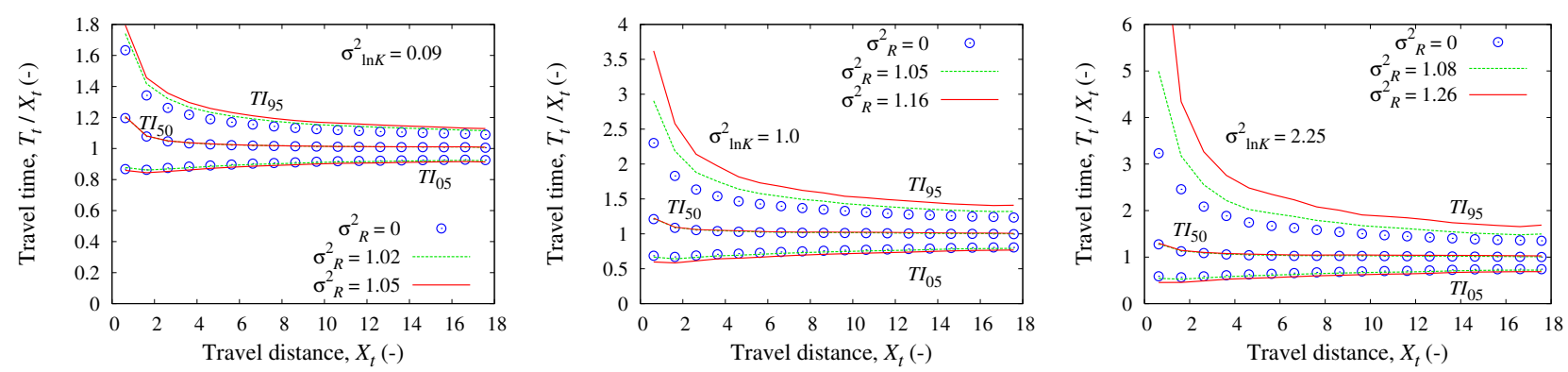

図-11 各不均質度に対するトラベル距離とトラベル時間の関係

$$
X_{t}=\xi_{P} / \lambda, \quad T_{t}=T I_{\varepsilon} \bar{K} J /\left(\lambda n_{p} \bar{R}\right)
$$

ここに, $X_{t}$ は粒子群のトラベル距離， $T_{t}$ は粒子群のトラ ベル時間, $T I_{\varepsilon}$ は評価面を通過する粒子群の累積質量の $\varepsilon$ パーセントに相当する時間, $\bar{K}$ は透水係数分布の幾何平 均, $J$ は動水勾配, $\bar{R}$ は対象場の平均遅延係数である.

図-11に示寸ように, $T I_{05}$ や $T I_{50}$ は化学的不均質性の 度合いに関わらず，ほぼ一致して推移しているのに対し て, 化学的不均質性の増加とともに, $T I_{95}$ の值, つまり は, 評価面を通過する粒子群の $95 \%$ 質量に相当する時間 は長くなっている，破過曲線の観点から考えると，テー リングの度合いが大きくなることになり, その結果, 式(10)における2次中心時間モーメント $\Lambda_{2, T}\left(\xi_{P}\right)$ の増大 につながる. したがって, 物理的不均質性のみならず, 化学的不均質性の高い場ほど, マクロ縦分散長は大きく なると言える。一方で, マクロ横分散長には式(11)の $\Delta b\left(\xi_{P}\right)$ が大きく関与寸る. 粒子初期位置からの水平変位 量は化学的不均質性よりも物理的不均質性の寄与が大き く, 場の流速分布とミクロ横分散長に影響を受けると推 量される.この点が図-8と図-9にて, マクロ横分散長が 化学的不均質性に低い依存性を示した要因である。

\section{4. 結論}

本研究にて得られた知見は以下のとおりである.

1. 時間・空間モーメント法ともに, 不均質度に関わら ず，類似したマクロ縦分散長の結果を導いた。一 方, 粒子群の初期配置は空間モーメント法によるマ クロ横分散長の推定に大きく影響を及ぼした。

2. 評価要素にてマクロ分散長を推定すると, マクロ縦 分散長は評価面よりも小さく, マクロ横分散長はほ ぼ同一の推定值となった。

3. マクロ横分散長の化学的不均質性への依存度は低い 一方で, 化学的不均質性の増加に伴って, マクロ縦 分散長は増加する傾向にあり, 物理的不均質性の高 い場ほど化学的不均質性の影響が顕著に現れた。

4. 粒子群のトラベル時間を検討した結果, 化学的不均 質性の効果は累積質量の高い部分, 寸なわち破過曲 線のテール部分に現れることがわかった.

\section{参考文献}

1) Dagan, G.: Solute transport in heterogeneous porous formations, J. Fluid Mech., 145, pp.151-177, 1984.

2) Uffink, G.J.M.: Analysis of dispersion by the random walk method, Ph.D Dissertation, Delft University of Technology, 150p., 1990.

3) Gelhar, L.W., Welty, C. and Rehfeldt, K.R.: A critical review of data on field-scale dispersion in aquifers, Water Resour. Res., 28(7), pp.1955-1974, 1992.

4) Adams, E.E. and Gelhar, L.W.: Field study of dispersion in a heterogeneous aquifer, 2. spatial moment analysis, Water Resour. Res., 28(12), pp.3293-3307, 1992.

5) Gelhar, L.W. and Axness, C.L.: Three-dimensional stochastic analysis of macrodispersion in aquifers, Water Resour. Res., 19(1), pp.161-180, 1983.

6) Tompson, A.F.B.: Numerical simulation of chemical migration in physically and chemically heterogeneous porous media, Water Resour. Res., 29(11), pp.3709-3726, 1993.

7) Wang, K. and Huang, G.: Effect of permeability variations on solute transport in highly heterogeneous porous media, Adv. Water Resour., 34, pp.671-683, 2011.

8) Hoehn, E., and Santschi, P.H.: Interpretation of tracer displacement during infiltration of river water to groundwater, Water Resour. Res., 23(4), pp.633-640, 1987.

9) Fernàndez-Garcia, D., Illangasekare, T.H. and Rajaram, H.: Differences in the scale-dependence of dispersivity estimated from temporal and spatial moments in chemically and physically heterogeneous porous media, Adv. Water Resour., 28, pp.745-759, 2005.

10) 井上一哉, Uffink, G.J.M., 田中勉 : 成層地盤のマクロ分 散に及ぼす物理的・化学的不均質性の影響に関する粒子追 跡アプローチ, 水工学論文集, 54, pp.607-612, 2010.

11) Bear, J.: Dynamics of fluids in porous media, Dover Publications, 764p., 1972.

12) Deutsch, C.V. and Journel, A.G.: GSLIB: Geostatistical software library and user's guide, Oxford University Press, 340p., 1992.

13) Ghori, S.G., Heller, J.P. and Singh, A.K.: An efficient method of generating random permeability fields by the source point method, Math. Geol., 25(5), pp.559-572, 1993.

14) 井上一哉, 島田遥, 田中勉: 溶質のマクロ分散とトラベル 時間に与える成層地盤のアップスケールの影響, 土木学 会論文集A2分冊(応用力学), 67(2), pp.I_521-I_532, 2011.

15) Zheng, C. and Bennett, G.D.: Applied contaminant transport modeling, Wiley Interscience, 621p., 2002.

(2012.9.30受付) 